Славен Стевановић

Факултет техничких наука, Нови Сад

e-mail: stevanovic.slaven@gmail.com

\title{
МОДЕЛ АРХЕТИПСКЕ КОЛИБЕ ПРЕМА САКРАЛНОЈ И ПРОФАНОЈ ПАРАДИГМИ
}

Апстракт: Човеково постојање на земљи је просторно. Архетипска колиба (прва кућа) представља материјалну конкретизацију човековог простора егзистениије. Поставке човековог простора егзистеничје се налазе у юеговим личним жсивотним парадигмама. Стога, основни задатак архитектуре јесте да конкретизује те различите човекове парадигме. Према М. Елијадеу две опште животне парадигме јесу: „,вето “ и „, профано“. Савремена архитектура конкретизује скоро искључиво „,профану“ човекову егзистенцију. У овом раду истражујем шта је то „света“ “овекова егзистенција, указујем на чињенииу да она и даље постоји, али и да је у архитектонском смислу запуштена. Архитектура има онтолошку обавезу да конкретизује егзистенцијални простор сваког човека, па тако и оног чија се животна парадигма дефинише као „света“.

Кључне речи: Човек, простор егзистеничје, животне парадигме, свето, профано, архетипска колиба, домаћа ирква, архитектура

\section{Уводна разматрања}

„Становање је начин на који смртници постоје на земљи.“1 Мартин Хајдегер „Свето и профано представљају два начина бивствовања у свету, две егзистенцијалне ситуације. ${ }^{\text {2 }}$

Мирча Елијаде „Једине детерминанте свеколиког људског живота на земљи јесу: човекобоштво и богочовештво.“3 Јустин Поповић

Архитектура је интердисциплинарна наука из врло простог разлога. Он лежи у елементу њене онтолошко-гносеолошке оријентације. Тај главни елемент, субјекат оријентације, genitivus subjectivus, може бити једино човек. ${ }^{4}$ Он је био, јесте и остаће, њено

1 Хајдегер 1982, 87.

2 Елијаде 2003, 15.

3 Поповић 1998.

4 Наравно, подразумева се да је у овом конкретном раду реч о словесно (разумски) створеној архитектури; а не о архитектури бесловесних бића, нпр. пчела, мрава, птица и сл. 
основно онтолошко-гносеолошко упориште. Њен творац и разлог постојања. Логично је, када не би било човека, не би било ни архитектуре за човека.

Стога, уколико је циљ расправљати о различитим моделима архетипске колибе, и то не само у смислу прве цивилизацијске куће, већ и као представе битка, темељних принципа, односно идеалне представе куће (свих времена и простора), онда управо човек мора постати главни елемент операционализације. Односно, када се постави проблемско питање: Шта је то архетипска колиба?, једини правац суштинског разрешења овог питања може ићи у правцу оног ради кога та творевина уопште и постоји. Спрам тога, могло би се поставити одређеније предметно питање: Какав је то човек спрам кога настаје архетипска колиба? Односно, та идеална кућа, први простор 5 његове животне орјентације и идентификације.

Наравно, постављајући проблем човека у ужи центар интересовања, цео проблем као да се додатно усложњава. Јер, како каже Свети Јустин Поповић: „Нема сумње, човек је после Бога најтајанственије и најзагонетније биће.“6 Слично би рекао и владика Његош: „Тајна чојку човјек је највиша!”7 Па чак и трагичар Софокле потврђује: „Много је чуда на свету, човек је од свих чудеснији.",

С обзиром да се питање човека поставља из разлога да би се решило питање првог архитектонског простора, онда би и операционализација целог проблема требало да иде управо у правцу те специфичне везе на релацији човек-простор. Горе наведени Хајдегеров цитат само потврђује да је човеково постојање на овој земљи просторно; односно обавезно праћено некаквим видом становања. Мирча Елијаде у својим истраживањима ближе одређује тај помало загонетни однос. ${ }^{9}$ Он појашњава да човек изискује одређени материјални простор како би могао да конкретизује свој егзистенцијални простор; те да у општем метафизичком смислу, тај први простор његове егзистенције и идентификације јесте простор дома, куће. Но, оно што је кључно, јесте да је свака та егзистенција човека врло специфична. Он сублимира и дефинише две опште егзистенцијалне ситуације и одређује их кроз термине: свето и профано. Врло слично тврди и Јустин Поповић када каже да проблематика човека, у најопштијем смислу, може бити сагледана кроз свега две призме: човека као човекобога и човека као богочовека. ${ }^{10}$

С обзиром да се ту ради о, како и Елијаде појашњава, двема „егзистенцијалним ситуацијама“, „начинима бивства у свету“, дубоким метафизичким одређењима, истовремено је, у ствари, реч и о две различите животне парадигме. ${ }^{11}$ Свети Јустин би то потврдио, али би их и јасно терминолошки дефинисао кроз појмове „антропоцентризма“ и ,теантропизма““. ${ }^{12}$ Или, можда још суптилније, као парадигму антропотеоцентризма и теантропоцентризма.

Ове две антиподске животне ситуације човека јесу истовремено и скуп најразличитијих уверења ка којима се све потребе човека концентришу и ближе одређују. Ова уверења, јасно је, јесу онтолошко-гносеолошке природе. Или према Св. Симеону

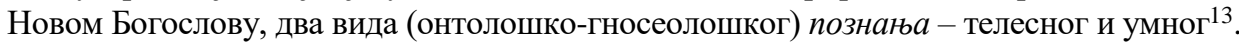

5 Више о првим егзистенцијалним и идентификационим просторима човека код: Пијаже 1990.

6 Поповић 2009, 113.

7 Петровић Његош 2001, 11.

8 Софокле 1996.

9 Елијаде 2010; Елијаде 2007.

10 Поповић 1998.

11 Елијаде 2003, 15.

12 Поповић 2003, 115.

13 Према: Ристић-Горгиев 2006, 41. 
Логично, архитектура, као дисциплина која подржава човекову егзистенцију на земљи, мора имати за циљ да сва та уверења и познања, тј. потребе, ма како оне биле различите и специфичне, задовољи на начин достојан човека. Односно, њен циљ мора бити да све просторно-егзистенцијалне потребе човека, без изузетка, материјално конкретизује. Кроз историју архитектуре може се видети да је она заиста увек била „консеквенца социјалне рефлексије“14. Или, како можда Гогољ сликовитије објашњава: „Архитектура је људска историја исписана у камену.“15

Тако, и савремена архитектонска продукција, спрам тренутне животне парадигме друштва унутар кога и настаје, највише одговара оној парадигми антропотеоцентризма, профаној животној оријентацији. Сакрална парадигма (теантропоцентризма) јесте скоро потпуно запостављена. Чак и кроз историју архитектуре гледано, питање сакралне егзистенције у архитектури никада није детаљније елаборирано, дефинисано, нити структурирано. Научно посматрано, докле год постоји човек чија је животна парадигма сакрална, ова запостављеност нема оправдања. Јер, чак и данас, у савременој организацији друштва, ишчезавање ,религија” никако не подразумева ишчезавање „религиозности”. Или, како још директно каже Елијаде: „Профани човек произилази из hото religiosus- $a$ и није у могућности да избрише сопствену историју (...) човек строго рационалан јесте апстракција и не среће се никада у стварности.“"16 Другим речима, чак и данас, када званична парадигма јесте профаност, религиозност и даље (бар у неком облику) постоји. Код неких припадника друштвене заједнице она је јасно истакнута и тежи ка конкретним религијама, а код других је она потиснута и запостављена, али никако уништена. Но чак и тако запостављена, она се испољава кроз различите облике и веровања, ${ }^{17}$ идеологије, митологије, сујеверја, епску фантастику, позоришта, филмове и сл.

Циљ овога рада, стога, јесте да бар једним делом осветли ту неоправдано занемарену сакралну димензију човекове егзистенције и њене архитектонске материјализације. То је нужно, јер човек чија је егзистенција сакрална, логично, свој простор идентификације не може наћи у созерцању и живљењу оне профане егзистенције. Тиме, архитектонски и научно је такође нужно елаборирати и јасно представити и ову другу, врло специфичну али свакако постојећу, сакралну животну парадигму човека. Јер, „духовне вредности (...) покрећу саму суштину људског бића а тиме и заједнице која гради насеље. “18 И још, како и врло директно каже Свети Јустин Поповић: „Не хуманизам - већ теохуманизам! Не човек - већ богочовек!“19 може бити једини легитимни и потребни парадигматски оквир просторне егзистенције религиозног човека.

\section{Профани егзистенцијални простори архетипске колибе}

„Егзистенција коју модерни нерелигиозни човек преузима јесте трагична (...) признао је себе за јединог субјекта и творца Историје а одбацио свако позивање на трансценденцију (...). Свето је препрека ка његовој слободи.“20

Мирча Елијаде

14 Зеви 1966.

15 Према: Ацовић 2014, 215.

16 Елијаде 2003, 148-49.

17 Елијаде 2003, 143-51.

18 Кузовић, 2019, 824.

19 Поповић 2009, 122.

20 Елијаде 2003, 144. 
Архитектонски простор човека чија је парадигматска позиција профана изразито се разликује од оног чија је парадигма сакрална. Да би се ова, помало мистификована сакрална позиција лакше разумела, било би корисно најпре дати кратак преглед ове профане парадигматске поставке.

У онтолошком смислу, једина истина за профаног човека јесте он сам. ${ }^{21}$ Његова вера је у човека и, последично, у човекове материјалне продукте. Никаква дубља трансцендентна сила не постоји. Сходно томе и његово гносеолошко одређење сврхе живота јесте на нивоу пуке физичности, телесних задовољстава и уживања. Један од идеолога модерне егзистенцијалне мисли са краја XIX века, Ниче, у том духу прокламује следећи позив: Човече, „Sei stolz und glücklich!“‘ („Буди поносан и срећан!“). Данас, у времену глобализма, индиферентизма и екуменизма, ${ }^{22}$ чини се да је свет више него здушно чуо и прихватио Ничеов позив; ${ }^{23}$ гордо себељубље ${ }^{24}$ постаје одлика савременог човека, али и савремене архитектуре.

Модерна мисао у архитектури такође то прихвата и одговара тзв. „модерном кућом за модерног човека“"25. Идеал нове куће јесте задовољење новоуспостављених потреба модерног човека. Таква, нова кућа је најпре градска кућа. Модерни човек напушта руралне пределе и, захваљујући развоју нових начина за рад (у фабрикама), одлази у град. Напушта сеоско домаћинство и породичну задругу. Нове породице су мале и углавном, услед различитих послова, раздвојене. Време када се породица окупи, проводи у новодефинисаним идеалима - уживања и одмора (често поново раздвојено по засебним стамбеним зонама). Или, како сликовито Елијаде каже, циљ профаних људи јесте „да одморе да би рад наставили“26. Тако, нова кућа, у ствари, постаје у правом смислу те речи „машина за становање“, како ју је победоносно дефинисао отац модерне архитектуре Ле Корбизје. ${ }^{27}$ Све више центар архитектонске мисли постају техника, технологија, форма, задовољење телесности; 28 човек, ради кога све то и настаје, његове мисли и осећања, поготову оне религиозне, губе свој центар оријентације. ${ }^{29}$

Нову кућу красе „серијска производња“"30 и ,домаћинска економија“31, засноване на профиту и на сведеним идеалима (рада, одмора и уживања). Таква кућа је, у свом естетском погледу, временом постала безлична. Серијска производња је произвела управо оно што јој је и било потребно - типизирану јединицу. ${ }^{32}$ Обезличену, хладну, банализовану „кутију“ за становање. ${ }^{33}$

Кристијан Норберг Шулц, један од најзначајнијих теоретичара архитектуре, критикује овај губитак идентитета и поново упућује на човека као на епицентар архитектонског деловања. ${ }^{34}$ Он истиче да ,архитектонски простор конкретизује човеково

21 Поповић 2009.

22 Радосављевић 2021.

23 Шпенглер 2010.

24 Шулц 2000.

25 Ле Корбизје 1999.

26 Елијаде 2003, 40.

27 Ле Корбизје, 1999.

28 Ле Корбизје, 1999.; Гиденс 1998.

29 Елијаде 2003.

30 Ле Корбизје 1999.

31 Ле Корбизје 1999.

32 Koolhaas 2014.

33 Радовић 2005.

34 Шулц 2000; Шулц 2009. 
постојање на свету“.35 Но, иако он сасвим јасно упућује на поштовање човекове егзистенције, његових „жеља и снова“, он никако није дефинисао ближе одлике те егзистенције. ${ }^{36}$ Није поставио питање шта уопште дефинише, ствара, уређује, те „жеље и снове“ човечијег опстанка. Јасно одређење парадигматске позиције човека, његова дубља метафизичка схватања живота, „жеља и снова“, разлога његовог постојања, нису дефинисана. Супротно, из ширег контекста његове теорије стиче се утисак да његова теорија подражава управо ону профану егзистенцију. На овај начин, како је време и показало, до суштинских промена у перцепцији проблематике архитектонског простора није могло доћи.

Без узвишене метафизичке и конкретно онтолошке вредности, таква профана кућа се у сваком тренутку може променити, као и свака друга „машина“. 37 То је ваљда и био циљ модерне мисли. Њена онтологија је у потпуно другачијим, световним, профаним, стварима; човеку и његовим продуктима. Она једноставно нема онтолошку дубину и значење које је првобитна сакрализована кућа религиозног човека имала.

Кућа религиозног човека се, супротно, не може тек тако напустити или заменити са неком другом. Јер, таква кућа „није некакав предмет, 'машина за становање', она је Универзум који човек себи ствара подражавајући узорно Стварање богова, космогонију“38; она дакле одсликава нови почетак, нови живот за религиозног човека.

\section{Сакрални егзистенцијални простори архетипске колибе}

Опште поставке: кућа - мала црква

„Религиозни човек може да живи само у сакралном свету, јер једино такав свет учествује у збивању бића, стварно постоји. Та религиозна нужност изражава неутољиву онтолошку жеђ. “39 Мирча Елијаде

Свака егзистенцијална потреба човека тежи свом простору конкретизације. Тако и ова потреба за религиозним, која је на нивоу „онтолошке жеђи“, како Елијаде каже, још више мора имати свој материјални простор конкретизације. Наравно, у сотериолошком смислу простор сам по себи није нужно круцијалан. Јер, „не спасава место човека“40, према сведочењу отаца Православне цркве, већ смирење; али, у најопштијем смислу, материјална конкретизација сакралности ипак јесте природна консеквенца човекове сакралне егзистенцијалне просторности.

Леп пример се налази код Св. Максима Исповедника, ${ }_{41}^{1}$ који каже да „чувствени свет није пролазна сенка, није распад или губљење бића, него припада пуноћи и целосности бића“. Јер, и тело и душа створени су ради сједињења са Господом, ради обожења, заједно, за бесмртност и живот вечни. Тело човеково у Православној цркви се уопште назива и „храмом Божијим“. Свети Јустин објашњава сву истинску лепоту и бригу Православне цркве и за тело, а не само за душу и каже: „Нико не обраћа на тело људско, на светост и бесмртност његову такву пажњу као Господ Христос. Он је учинио

35 Шулц 2000, 18.

36 Шулц 2000, 68.

37 Ле Корбизје 1999.

38 Елијаде 2003.

39 Елијаде 2003, 49.

40 Добротољубље 2009.

41 Радосављевић 2019. 
све да му осигура бесмртност и вечност.“442 Дакле, он је и умро за човека (за целог човека); а затим и устао из гроба, васкрснувши и човеково тело и душу. Оваква брига је, бар из угла цркве, далеко узвишенија од оне какву савремено либералистичко друштво слобода гаји према култу тела.

Стога, најверодостојније дефинисање и указивање на везу између земаљске егзистенције човека, његове материјалности и духовне потребе за небеским, долази од стране отаца и светитеља цркве Божије. У овом раду фокус ће бити управљен на наводе отаца Православне хришћанске цркве.

Тако, један од највећих богословских умова нашег времена, Свети Јустин Поповић богослови: „Домаћа ирква? - Породица. Да, то је црква у маломе. У Великој Цркви мала црква. Али и у њој сав живот као и у Великој.“43 (подвлачења су ауторова)

Ова мисао аве Јустина би се практично могла схватити као својеврсни манифест сакралне егзистенције човека. Манифест који можда најпотпуније сублимира каква то сакрална егзистенција човека у архитектонском смислу треба да буде. Елијаде је слично тврдио како сакрални човек не само да има потребу да живи близу светих простора, у храму Божијем, већ и да се његова „сопствена кућа нађе у Центру света и буде imago mundi “44. Место где се земља и небо додирују. Св. Јустин то дакле потврђује, али и ближе предметно конкретизује, узвишава и назива човеков простор битисања, његову кућу домаћом црквом. Но он иде и даље од тога, те не претпоставља само кућу, већ и целу породицу човека, цео дом његов, као „домаћу цркву“. Слично аналогији човека као микрокосмоса смештеног у макрокосмос, тако и овде - једну малу породичну цркву у великој васељенској породичној цркви.

Речи Светог цара Давида, у овом тренутку као да добијају пуније значење: „За једно само молим Господа, само то иштем, да живим у дому Господњем све дане живота својега, да гледам красоту Господњу, и раним у цркву његову“ (Пс: 26,4).

Живети у дому Господњем јесте идеал сакралног човека. Најпре у виду достизања вечног живота у истинском дому Божанства, у Есхатону. Но, знајући да је „царство Божије унутра у Вама“ (Лк. 17, 21) још овде, у овој земаљској пролазности, човек је свакако позван да испуни свој идеал и доживи да се усели у тај страшни и дивни дом Господњи. Живећи светотаинским животом, испуњавајући правила Цркве Божије, обогаћујући себе хришћанским врлинама, чистећи се од страсти и греха, он постаје подобан да се у њега самог усели Царство Божије.

Но, поред тога, овај улазак у Дом Господњи се може схватити и у виду борављења унутар црквених грађевина, поготову за време свете Евхаристије и најсветијег њеног тренутка освећења Светих дарова и Светог причешћа, живог сједињења са Творцем Својим.

Али, ава Јустин благовести да ту није крај; црквена грађевина није једини материјални простор у ком човек може да живи као у дому Господњем. Логично, човекова тежња ка Господу коју тако осећајно Цар Давид описује, жеља ка том животу у његовом дому, нити престаје нити почиње уласком, односно изласком из црквене грађевине. Ова жеља је константа и стално потребна. Тиме његова природна унутрашња потреба заиста јесте, како Елијаде рече, да и свој сопствени дом учини „Центром света“, центром божанства, тј. према речима Св. Јустина - „домаћом црквом“. Сама типологија простора стога не би смела да буде препрека, када је реч о циљу обожења човекова. Типолошки избор цркве као места вршења светих тајни, Свете Евхаристије, свакако јесте

42 Поповић 2005.

43 Поповић 1998, 158.

44 Елијаде 2003, 34. 
најприроднији и најподеснији. Али, како сведоче Свети оци, када је реч о самом процесу обожења и свака кућа човекова је позвана да постане управо једна мала црква; дом обожења њених станара.

Чак и традиција слављења крсних слава, карактеристична за србски народ, сведочи томе. Свети Сава је предајући свом народу завет слављења крсне славе имао на уму управо ту тежњу да сваки дом постане и једна мала црква. Слава је у томе припомогла јер славећи славу, породица у ствари прославља свог небеског заштитника на небесима. Тиме, тај православни дом, по угледу на Велику Цркву, добивши свог небеског покровитеља, уједно постаје и једна мала, домаћа црква посвећена том светитељу.

Ава Јустин даље сведочи и да у таквој домаћој цркви живи својим животом и сва пунота Велике Цркве: „у Великој Цркви мала црква. Али и у юој сав живот као и у Великој: иста Истина, иста Љубав, исте светиње, исте тајне, исте врлине, исте силе, исти закони, исто Еванђеље.“"45 (подвлачења су ауторова). Дакле, исти Господ Исус Христос, иста црква његова, једна, Света, саборна и апостолска. Тиме, свака је православна кућа неизоставно позвана да постане домаћа црква. Свака је породица позвана да постане Света. Поштујући ту једну онтолошку Истину и Љубав, гносеолошку сврху свог постојања у виду обожења, аксиолошко-методолошка мерила владања, стицања светих врлина и светотајинског живота, егзистенција такве породице мора бити сакрална. Тиме је сасвим јасно и логично да архитектонски простори конкретизовани профаним егзистенцијалним поставкама живота, не могу бити одговарајући за човека чија је егзистенција сакрална.

\section{Егзистенцијалност као животна парадигма}

Овај проблем егзистенцијалности човека у научној литератури, поготову када је реч о њеној архитектонској манифестацији, често није дубље, систематичније истраживан. Питање егзистенције у смислу сакралности и/или профаности архитектонских простора, скоро је потпуно маргинализовано. Кристијан Норберг Шулц, један од најзначајнијих савремених теоретичара архитектуре, који се највише бавио архитектонским просторима човекове егзистенције, управо је добар пример исказаног. Не одређујући ближе (метафизику) природу егзистенције, он суштински тај проблем на нивоу архитектонских промишљања и није решио. ${ }^{46}$ Супротно томе, добар показатељ како се проблем егзистенције може разрадити на једном вишем нивоу јесте спомињани Мирча Елијаде. ${ }^{47}$ Његова историјско-феноменолошка, тиме у одређеном смислу и метафизичка истраживања, и подела егзистенције на свету и профану компоненту, добар су показатељ у ком правцу треба ићи.

Водећи се његовим истраживањима, уочава се да овде спомињане егзистенцијалне позиције јесу и нешто више од пуке терминолошке одређености проблема човекове егзистенције. Комбинујући истраживања Елијадеа, али и мисли Светих отаца, долази се до мисли да питање природе човекове егзистенције у ствари јесте поставка целокупног његовог живота. Фундамента, на коме, и према коме, човек одређује свој начин битисања у овом свету. Полазећи од ближег схватања семантичких значења термина егзистенције, ближе се утврђује да она представља управо „начин, и или модел живота“. Али, одатле произилази и можда суптилнији термин у виду појма „парадигме“. Њено семантичко

45 Поповић 1998, 95.

46 Шулц 2000.

47 Елијаде 2003. 
значење је практично врло слично, али спрам контекста истраживања и интенција које се овде покушавају представити, чини се да би овај термин био подеснији за даљу расправу.

Стога, могло би се закључити да, када се расправља о различитим егзистенцијама човека, погледима на свет, живот, у ствари се истовремено говори и о различитим животним парадигмама. Ово је значајна информација најпре због тога што термин парадигме олакшава истраживање метафизичких полазишта неке егзистенције. Односно, користећи термин парадигме омогућава се један научно структуриранији и тиме подеснији приступ.

Сходно предоченом, потребно је издвојити мишљење Губе и Линколна (иначе у једном од до сада најцитиранијих научних текстова), где кажу: „Парадигме су основни системи веровања. Засновани на онтолошким, епистемолошким (гносеолошким) и методолошким претпоставкама.“48 Касније, многи аутори, попут Холмса и Линдсија суптилно додају и још једну категорију, о којој и сами Губа и Линколн на свој начин већ расправљају, и кажу: „Есенцијалне компоненте темеља на којима се методолошке стратегије (у ширем контексту текста мисли се на парадигме - прим. аут.) углавном граде, обухватају (...) онтологију, епистемологију и аксиологију.“49

Дакле, из овога се може закључити да је и егзистенција неке сакралне породице чији је труд усмерен ка формирању свете егзистенције, у ствари, разложеније постављено, усмерен ка познању онтолошке Истине, гносеолошке сврхе у виду обожења, аксиолошкометодолошких врлина и светотајинског живота. Што све, у ствари, јесте и јасан избор погледа на свет, начин живота, односно коначно - једне животне парадигме.

\section{Симболичка конкретизација сакралне парадигме}

Када је реч о конкретизацији ове сакралне парадигме на ниво човекове куће, или у теорији архитектуре - архетипске колибе, идејно-материјални конструкт који чини ту конкретизацију могућом јесте исто тако одређен управо терминима онтологије, гносеологије, аксиологије и методологије. Разложеније посматрано, почетна идеја, основно полазиште, веровање на којима се заснива идеја стварања неке куће (архетипске колибе) мора бити унутар онтолошко-гносеолошких становишта њеног творца. Последична физичка материјализација тих ставова се даље изражава кроз њихову симболичку конкретизацију праћену аксиолошким оквирима и уз помоћ конкретних методолошких стратегија стварања.

Проблем и процес ових симболичких конкретизација посебно је обрађивао и Свети Максим Исповедник. У његовим делима се може наћи својеврсни наставак на мисли Св. Јустина Поповића или, у одређеном смислу, дубље богословско образложење тог тако мистичног односа на релацији дома човечијег и дома Господњег. ${ }^{50} \mathrm{y}$ својој божанској Мистагогији ${ }^{51}$, у поглављу у ком се бави грађевинским објектом цркве посматраном као духовно-телесном сликом света, Свети Максим наводи мисли једног мудрог Старца и каже да је: „Црква Божија знак и слика целокупног света који се састоји из суштина видљивих и невидљивих, јер се у њој огледа и јединство и разлика, као и у њему. "52

48 Guba \& Lincoln 1994, 105-117.

49 Holmes \& Lindsay 2018.

50 Радосављевић 2019.

51 Радосављевић 2019.

52 Радосављевић 2019,179. 
Уколико би се покушало операционализовати и ближе појаснити, ова мисао би се могла и овако представити: Црква Божија (у контексту грађевине) је (симболички) знак и слика целокупног (нерукотвореног) света (чувственог, телесног) који се састоји из суштина видљивих (телесних) и невидљивих (духа, душе), јер се у њој огледа и јединство (у Христу), и разлика (у људима), као и у њему (у свету).

Другим речима, он покушава са једне стране да црквену грађевину посматра као симболичку конкретизацију целокупног света, видљивог и невидљивог, тј. као imago mundi (што је и Елијаде тврдио за храм); а са друге стране да управо тај нерукотворени, чувствени и телесни свет исто тако представи кроз призму премудро-симболички конкретизоване Цркве. ${ }^{53}$ У контексту расправе и спрам интенција постављених у овом раду, ово тумачење чувственог и телесног света спрам симболизма Црквене грађевине, јесте од кључне важности.

Имајући на уму мисли да се овај телесни (нерукотворени) свет може представити кроз слику Цркве, те и да свака (рукотворена) кућа треба да постане мала црква, могли бисмо индуковати да тако и свака та (рукотворена) кућа у ствари може бити замишљена и конкретизована управо кроз ту слику Црквене грађевине, односно слику целокупног видљивог и невидљивог света.

Тако, као што цео овај свет постоји као црква у светлу једне јединствене ипостаси састављене од олтара и храма, ${ }^{54}$ тако и свака кућа човека, која претендује да постане мала црква, може се симболички посматрати као исто такво јединство од олтара и храма. „Олтар“ неке куће (домаће цркве), у симболичком смислу, представља просторну конкретизацију посвећену вишњим силама и тиме духовну везу са горњим светом; док део „храма“ неке куће (домаће цркве) јесте остатак простора намењен телесној човековој егзистенцији. ${ }^{55}$

Можда интересантан пример јесу породичне куће на локалитету Трговишта код Новог Пазара, али и већина старих средњовековних насеља која су настајала уз манастирске комплексе, а у чијем је склопу једна од просторија била посебно организована као кућна капела. Тако, та капела је симболички представљала управо тај олтар, везу са небеским светом, док је остатак просторија бивао храм, намењен осталим чувственим потребама човека. Иако функционално подељена, та кућа је свакако и даље постојала као једна засебна целина, јединствена и недељива попут цркве коју и симболише.

Слична веза симболичке конкретизације, када је реч о тој средњовековној кући сакралног човека, била је уприличена и на свим другим просторним нивоима. На пример, када је реч о организацији дневне зоне, углавном је некада подразумевано и постојање огњишта као централног елемента оријентације. Његова симболичка улога је на првом месту била управо духовна. Ватра и уопште централност огњишта су представљали директну симболичку конкретизацију Бога и божанствене светлости. Огњиште је било својеврсни елемент „комуникације“ са оностраним, различитим облицима давања заклетви, благосиљања, молитве, па у неким културама и жртвоприношења. Слично је, на пример, и са кућним прагом (као симболом прелаза из профаног у свето), степеништима (путевима уздизања га божанству), угловима објекта и централним стубовима (схватаним као axis mundi), са иконама и сличним елементима. Све те различите хијерофаније (како их Елијаде назива) су са једне стране биле директна манифестација Светог и веза са небесним, али и, са друге ране, конкретан физички елемент који је духовни свет ипак

53 Радосављевић 2019, 179.

54 Радосављевић 2019, 178-79.

55 Радосављевић 2019, 179-80. 
привлачио физичком свету, задржавајући га унутар просторних граница тог храмовног дела куће.

Исказано је потенцијално видљиво на свим просторним нивоима. Елијаде тако наводи примере и о урбанистичким решењима (у Кини, Старом Риму, Индији, Турској и сл..), која су de facto била поређења сакралним перцепцијама њихових градитеља и целокупне друштвене заједнице. Слична истраживања је спроводио и проф. Кузовић доказујући како је улога сакралних објеката у формирању идентитета насеља била више него значајна. Он тако наводи: „физичка форма торња (мисли на цркву - прим. аут.) је била и материјализација вертикале духовних вредности око којих се окупља заједница која гради насеље“"56. (подвлачења су ауторова)

Овај перихоризис - узајамно прожимање двају природа, духовне и материјалне - Свети Максим схвата као важан извор сазнања, како видљивог, тако и невидљивог света. Јер, како каже: ,за оне који имају моћ да виде, сав духовни свет одсликава се на тајанствен начин у целокупном чувственом свету у симболичким сликама. А сав чувствени свет по умном сагледавању, показује да садржи у целокупном духовном свету.“57 Тако, созерцањем невидљивог помоћу видљивог, односно помоћу „отисака“ невидљивог, његових материјалних симболичких представа, долази се до спознаје тог невидљивог. Али исто тако, и созерцањем видљивог помоћу невидљивог, односно помоћу „логоса“ видљивог, његових идејних значења, концепција, долази се до спознаје тог видљивог. Тако и оно огњиште, као видљиви елемент, може се ближе спознати созерцањем његових невидљивих, духовних значења, логоса; док, са друге стране, и та духовна значења, логоси, могу бити јаснији кроз созерцање њихових „отисака“, материјализације у виду тог огњишта.

Слично и Филип Ивановић тумачи Дионисија Ареопагита када пише о феномену симболичких конкретизација: „Иако је крајњи циљ усхођења домен без форме (Бог, обожење - прим. аут.), овај пут почиње стварима које поседују форму. Слика и визија стимулишу ум у његовом лету... Симболички језик превазилази снагу дискурзивног језика."58 Дакле, визуелна репрезентација форме, простора, односно слика, јесте једна од значајних одлика процеса обожења. Јер, сами људи су чулна, тиме и визуелна бића; поред умствене, духовне, спознаје они поседују и ту чувствену способност спознаје помоћу чула. Стога, у контексту усхођења ка Богу и процесу обожења, слика, или другим речима „символи и сигнали“59 играју одређену, значајну улогу. Дионисије пак сам, у наставку, егзактно објашњава изнето: „Наш ум другачије не може усходити ка висинама и созерцавању небеских чинова осим кроз (посредством) њему својствених вештатствених руководстава, тј. кроз прихватање видљивих одраза у покушају да се објасне (појме) невидљиве красоте, да се кроз светлост материјалних твари изобрази невештаствено озарење; (...) сав поредак видљивих красота (украса), постојано указује на небеса (...). Да будемо још краћи: све радње које принадлеже небеском, нама су (због природе наше најчешће) предати кроз симболе.“60

Слично се налази и код божанственог Павла када каже: „Што је на Њему (Богу) невидљиво, од постања света умом се на створењима јасно види“ (Рим 1, 20). Или и код Св. Владике Николаја, који је цело једно богословско дело Симболи и сигнали ${ }^{61}$ посветио

56 Кузовић 2019, 824.

57 Радосављевић 2019, 180.

58 Ivanovic 2010.

59 Велимировић 2013; Продић 2012.

60 Ivanovic 2010.

61 Велимировић 2013. 
управо овој вези мисаоног и чувственог, невидљивог и видљивог, духовног и телесног, односно њиховим симболичким конкретизацијама.

Сходно свему изнетом, могло би се коначно закључити да човек који тежи сакралној егзистенцији, тј. чија су животна парадигма и његова унутрашња онтолошкогносеолошко-аксиолошко-методолошка веровања сакрална, потребује исту такву просторну конкретизацију. Један од начина који би, према Светим оцима, могао бити подесан, јесте устројити дом тако да он постане Мала црква. Кућа човека тако постаје јединствени организам где се уз помоћ симболичких конкретизација међусобно спајају видљиво и невидљиво, духовно и телесно. Кућа постаје црква где се „небо оземљује и земља онебесује“. 62

Један од најпознатијих теоретичара архитектуре Ранко Радовић је говорио: „Куће су заиста као људи, или још боље - оне су људи.“63 Исто тако, један од најпознатијих богослова данашњице, Св. Јустин је говорио: „Црква - то је Богочовек Христос (...), но исто тако, Црква је и човек - продужен Богочовеком Христом кроза све векове и кроз сву вечност.“64 Дакле, ако кућа јесте човек, ако и црква јесте човек, онда и кућа јесте црква; али како и Св. Јустин ближе одређује: кућа јесте ирква али само кроз Богочовека Христа. Да би заиста постала црква, та њена парадигматичност мора бити одређена како онтолошком истином Христа, гносеолошком сврхом обожења у Христу, аксиолошким вредносним мерилима датим од Христа и методолошким начинима достизања до свега дефинисаног, такође уређеним Христом. Схватити суштину куће на којој се темељи, сврху ка којој тежи и ради чега постоји, усвојити вредности којим постоји и којима тежи, начине за достизање тога; то је задатак архитектуре и права природа куће човекове ма које животне парадигме, а најпре оне сакралне.

\section{Закључна разматрања}

Спознати суштину ма и једног проблема није лако. Тако и питање онтолошкогносеолошке суштине архитектуре и њене прве куће, или уопште куће, никада није и неће бити лако. Један од начина и могућности приступа овом проблему дат је и у овом кратком прегледу.

Главни кључ за одгонетање тог почетка сваке куће, сваке архитектуре, овде је претпостављен и представљен у виду човека, као главног творца, субјекта сваке архитектуре. Конкретније, у виду његовог егзистенцијалног простора. Још суптилније, у виду његове конкретне егзистенцијалности, односно избора између сакралног и профаног начина битисања у свету.

Виктор Бичков, користећи се теоријом Св. Августина можда лепо сажима тај профано-сакрални егзистенцијални однос и потврђује да постоје два града различитих егзистенција. Један је град Божији где спадају сви они који желе да живе „по духу“ (secundum spiritum), „,о Божијим законима“, а други је град земаљски, оних који живе „по телу“ (secundum carnem), односно - „по људским правилницима“. ${ }^{65}$ Или, баш по речима Св. Августина, „два града - безбожника и праведника постоје од настанка људског рода и постојаће до краја света. (...).“66 Два града су последица две врсте љубави - „земаљски

62 Пјевач 2001, 154.

63 Радовић 2001, 11.

64 Поповић 1998, 30.

65 Бичков 2010, 368 .

66 Бичков 2010, 368. 
је саздан љубављу према самима себи, која доводи до презирања Бога, а небески љубављу према Богу, која доводи до презирања самога себе““.67

Дакле, профана егзистенција управо човека поставља у сам центар своје оријентације; трансцендентно за таквог човека не постоји. Тачније, према Елијадеу, „он ће достићи лични идентитет само уколико се темељно демистификује, биће збиља слободан тек у тренутку када убије и последњег бога“. ${ }^{8}$ Кућа таквог човека, и уопште архитектура као последица ових ставова, постаје изузетно нестабилна, нехомогена, аморфна, стално променљива, покретна, јасно неодређена ${ }^{69}$. Савремена кућа модерног човека, и цео модерни покрет на челу са Ле Корбизјеом о томе јасно сведоче. Савремени човек једноставно у таквим условима не може остварити такву егзистенцијалну сигурност какву је човек архаичних друштава имао. Шулц закључује да његовом кућом влада осећај „изгубљености и беспомоћности“70.

На супротној страни, сакрални човек за центар своје оријентације поставља Бога. Парадигматски темељ његове егзистенције, онтолошко-гносеолошко-аксиолошкометодолошка уверења, свој извор налазе у тој божанској трансцендентној сили. Кућа таквог човека, логично, свим својим бићем, и метафизичким и физичким, тежи задовољењу те потребе за божанским, за светим. Штавише, човекова тежња је директно управљена ка једном космогонијском начину градње сопствене куће. Он жели да живи у Центру света, да и његова сопствена кућа постане imago mundi, храм божанства. ${ }^{71}$

Према оцима Православне цркве, природно би било за верујућег човека да врлинским, светотаинским животом у цркви, он заиста омолитвени и свој лични дом, те и своју кућу, заједно са својом породицом, у ствари претвори у једну малу, домаћу цркву. Угледајући се на Велику Цркву, њено устројство и космогонијски стваралачки принцип, тако и мала црква треба да тежи да уз помоћ симболичких конкретизација постане манифестација светог, оностраног, веза видљивог и невидљивог, земље и неба, Бога и човека.

Према Лазару Абашидзеу сви предмети и цела архитектура хришћанског храма јесу управо такви да „симболично рефлектују премудри и преславни Домострој Божији, да подсете на њега и да га собом изобразе“. ${ }^{72}$ Сходно том циљу, храм се претвара у „складну, мелодичну, вишегласну песму“73. Све је „складно и равномерно, све је потчињену ритму, поретку и строгом распореду; све има своје правило - канон, меру, поредак. И свему постоји послушност, у свему постоји хијерархија, усклађеност, устремљеност ка Небу, смирење и лепота. "74 (подвлачења су ауторова). Исто тако, како он у наставку сведочи, и „свака травчица или цветић, сваки извор, свака бубица (...) пурпурни залазак сунца, жућкасто-црвени јесењи лист који је пао са дрвета, заслепљујуће бела чипка снега (...) јутарњи освит са живахним цвркутом птица, весело пролећно сунашце, звонки поточићи усред снега који се топи, отварање пупољака (...) све је то громогласна проповед о васкрсењу из мртвих (...) о вечности (...) о животу“"75.

67 Бичков 2010, 368.

68 Елијаде 2003.

69 Елијаде 2003; Шулц 2010.

70 Шулц 2010.

71 Елијаде 2003.

72 Абашидзе 2019, 352.

73 Абашидзе 2019, 353.

74 Абашидзе 2019, 353.

75 Абашидзе 2019, 353. 
Управо све ове хијерофаније, симболичке манифестације и конкретизације јесу уједно и конкретно методолошко упутство, како ту тежњу за сакралним, свету атмосферу храма Божијег, пренети на ниво куће, тај такође мали и домаћи храм Божији.

Доказ да то и није толико неоствариво најпре се налази у архитектури оних народа који су (најпре) у својој прошлости изразито тежили сакралном, чија је егзистенција била управљена светом животном парадигмом. Таква архитектура је углавном вернакуларна, спонтана, природна. Бернард Рудофски у својим делима сведочи постојање једне такве архитектуре, али и те помало мистификоване везе куће и божанског. ${ }^{76}$ Слично се може наћи и у расправама о архетипској колиби као рајској кући код Рикверта, ${ }^{77}$ додатно, и код Рајта, ${ }^{78}$ Александера,${ }^{79}$ па и нашег Радовића, ${ }^{80}$ могу се наћи јасне интенције ка дефинисању архитектуре, њене прве куће као својеврсне духовнотелесне творевине. Наравно, ван контекста православне вере али, без обзира, на то, намера ка повезивању светог и земаљског је више него јасна и тиме битна за спознају. Свака та интенција практично даје легитимитет овде представљеном виђењу.

Сходно свему предоченом јасно је и логично да кућа саздана према профаној парадигматској позицији никада, ни метафизички, ни физички, не може у потпуности задовољити човека чија је егзистенцијална парадигма сакрална. Он може, сходно приликама и неприликама, заиста живети у њој (како и живи савремени сакрални човек), али пунота његове егзистенције није остварена. Стога, природно би било да савремена архитектонска продукција своје снаге усмери управо ка свом основном задатку постојања - задовољењу свих потреба сваког човека. Тиме последично и специфичних потреба овог сакралног човека. Управо ово би био научно оправдан став. Свако занемаривање реално постојећих и тиме чињеничних потреба човека који себе сматра за сакрално биће, било би научно, али и по свим моралним мерилима, неприхватљив став.

Заокружујући расправу, као подстицајна мисао али и легитимност раду, наводи се и извод из изузетно значајног текста, исто тако значајног аутора Ле Корбизјеа ${ }^{81}$. Његове мисли, писане током боравка на Атосу, верујемо, на добар начин одсликавају важност дубље спознаје оне духовне позадине архитектонског стваралаштва:

„Православна вера, расадник мистицизма, преноси верне у блаженство (...) ова архитектура (...) заслужује моје дивљење и ја проводим сате у дешифровању њеног чврстог и догматског језика (...) Сасвим снажно сам осетио да је једини и узвишен задатак архитекте да отвори душу поетичним изарствима користећи материјале са интегритетом да би их учинио корисним. Обезбедити Мајци Божијој кућу од камена која је заштићена од старих злочина и уредити обим тог светилишта тако да дух исијава из њега, изазивајући мистериозне односе облика и боје, поштовање према свакоме, тишину на уснама, и не будити ништа више но уздизање молитве и певање свечаних песама у ритму контролисаног светла. Божански позив за старе градитеље! Чистота њиховог ичиља, њихових напора је изгубљена. Дисциплина је нама непозната, данашњим фушерима. Господе! Како је болна била екстаза која нас је захватила у тим источњачким храмовима. Како сам се осећао повучен, осрамоћен. (...) Моћно јединство овог језика је

76 Рудофски 1976.

77 Rykwert 1972.

78 Wright 1974.

79 Alexander 1979; Alexander 2002.

80 Радовић, 2001; Радовић 1979; Радовић 2005.

81 Помало парадоксалан пример иначе, с обзиром да је реч о аутору кога историја архитектуре и уметности сматрају оцем модерне, профане архитектуре. Али ипак значајан и легитиман. 
тако озбиљно да са овим утиском може да се упореди чврстоћа дијаманта“ 82 Ле Корбизје, 1911. године (сва подвлачења су ауторова).

Слично датом, као закључна мисао, прилаже се и опис једне просте сељачке куће Ранка Радовића. Приказ ове куће у великој мери подсећа и на опис вредности унутар једног сакрализованог простора, како су то наведеним речима описивали и Лазар Абашидзе и Ле Корбизје:

„Видео сам много соба светом и по књигама, али ме је највише обрадовала $u$ научила велика соба нашега кума Савељића, једноставног сељанина у црногорском селу Мартинићи (...) Његова је соба пространа, без много намештаја, без украса и без сувишности. Кревети од једрог дрвета постављени су дуж чистих, белих зидова. Средишьи простор остао је тако слободан, подложан променама и стално другачијој употреби тихих укућана. Плафон у дугим талпама, таман и матиран, спуштен до подигнуте руке. Под се жути, али не од боје, него од јасноће дрвета. Четири су једноставне столице у соби. Усправне, са строгим наслонима, пуне достојанства. Оне бележе велико огледало између два мала прозора отворена према долини и са дрвеним капциима, који су непријатељи и летње жеге и ветра са кишама. Уместо стола-непресушна шкриња наслоњена је на зид. Она је велики знак породичног блага, скровиште ткања и дугих бдења, окриље и везења и снова! У једном великом раму безброј породичних фотографија сакупљају време још од првих фотографа старе Подгорице. То је фреска породичног континуитета у којој величине слика и фигура непогрешиво изражавају значај и љубав коју је свако од нас стекао овде у домаћиновој соби и сећању. Боје су собе сведене и само јарке покривке надгледају кревете као цвеће поља.

И то је све... Све осим јагњећих кожа пред сваким креветом за први, топлији сусрет са новим и мукотрпним радним јутром... сутра, увек и поново...Сем достојанства и сврсисходности у овој соби живела је и недвосмислена лепота, печат једноставног, дух истине, сјај скромности због које је и била толико раскошна... (...) Нису због тога ови редови о соби нашега кума Савељића романтичарска носталгија за „прошлим“, Они су пре жудња за истинском архитектуром, која не разуме границе времена и не признаје привилеговане средине. Будућност је архитектуре, будућност је наших соба, свуда где је бит живюта изнад скупог декора.“ 83 Ранко Радовић, 1974. године (сва подвлачења су ауторова).

\section{Литература}

Alexander, Christopher (2002): The Nature of Order: An Essay on the Art of Building and the Nature of the Universe; The Phenomenon of Life. Berkeley, Calif: Center for Environmental Structure

Alexander, Christopher (1979): The Timeless Way of Building. New York: Oxford University Press

Guba, Egon; Yvonna, Lincoln (1994): Competing Paradigms in Qualitative Research, in: Handbook of Qualitative Research, ed. Norman K. Denzin, Yvonna S. Lincoln, 105-17. Thousand Oaks, Calif: Sage Publications

82 Ле Корбизје 2008.

83 Радовић 1979. 
Holmes, Colin, David Lindsay (2018): In Search of Christian Theological Research Methodology. New York: SAGE Open 8, no. 4 (October 1, 2018): 2158244018809214. https://doi.org/10.1177/2158244018809214.

Koolhaas, Rem (2014): Fundamentals: 14th International Architecture Exhibition - La Biennale Di Venezia. Venice: Marsilio Editori

Rykwert, Joseph (1972): On Adam's House in Paradise: The Idea of the Primitive Hut in Architectural History. New York: Museum of Modern Art

Wright, Frank Lloyd (1974): The Natural House. New York: Bramhall House

Абашидзе, Лазар (2019): Души обремењеној духом чамотиње, у: Жалосна је душа моја до смрти. Београд: Православна мисионарска школа при храму Светог Александра Невског

Ацовић, Драгомир (2014): Речник појмова ликовних уметности и архитектуре, Том 1 A- $Ђ$. Београд: САНУ, Завод за уџбенике

Ареопагит, Дионисије (2012): Дела, Corpus Areopagiticum. Шибеник: Истина Епархија далматинска

Бичков, Виктор (2010): Естетика отаща цркве. Београд: Службени гласник

Велимировић, Николај (2013): Символи и сигнали. Шабац: Глас цркве

Гиденс, Ентони (1998): Последище модерности. Београд: Филип Вишњић

Елијаде, Мирча (2007): Мит о вечном повратку. Загреб: Јасенски и Турк

Елијаде, Мирча (2003): Свето и профано. Нови Сад: ИК Зорана Стојановића

Елијаде, Мирча (2010): Слике и симболи. Сремски Карловци: ИК Зорана Стојановића архитеката

Зеви, Бруно (1966): Како гледати архитектуру. Београд: Клуб младих

Ивановић, Филип (2010): Визуелни аспекти обожења по Дионисију Ареопагиту. Београд: Зборник радова Византолошког института 47

Кузовић, Душко (2019): Улога сакралних објеката у идентитету насеља Балкана. Ниш: Црквене студије, 16/2

Ле Корбизје (1999): Ка правој архитектури. Београд: Грађевинска књига

Ле Корбизје (2008): Путовање на исток. Лозница: Карпос

Његош, Петар II Петровић (2001): Луча тикрокозма. Подгорица; Цетиње: Октоих; Светигора

Пијаже, Жан (1990): Психологија детета. Сремски Карловци: ИК Зорана Стојановића

Пјевач, Невенка (2001.): Азбучник богочовечанских мисли аве Јустина. Београд: самостално издање

Поповић, Јустин (2005): Зеница трагизма, у: О Духу Времена. Политика, Народна књига

Поповић, Јустин (2009): Православна ирква и екуменизам. Света Гора Атонска: Манастир Хиландар

Поповић, Јустин (1998): Тумачење посланице Светог апостола Павла: Ефесиима, Филипьанима и Колошанима, Галатима и I и II Солуњанима. Београд: Наследници оца Јустина и Манастир Ћелије

Поповић, Јустин (1998): Философија и религија Ф. М. Достојевског. Београд: Наследници оца Јустина и Манастир Ћелије

Радовић, Ранко (1979): Живи простор. Београд: Независна издања

Радовић, Ранко (2001): Нова антологија кућа. Београд: Грађевинска књига

Радовић, Ранко (2005): Нови врт и стари кавез. Нови Сад: Стилос 
Радосављевић, Артемије (2009): Православље и савремени изазови код нас. https://svetosavlje.org/pravoslavlje-i-savremeni-izazovi-kod-nas/?pismo=cir., приступљено: 20. 2. 2021.

Радосављевић Артемије (2019): Свети Максим Исповедник - изабрана дела: Подвижничко сово, Главе о љубави, Мистагогија. превео и сабрао: вл. Артемије Радосављевић. Београд: А. Радосављевић

Ристић-Горгиев, Слађана (2006): Гносеологија Светог Симеона Новог Богослова, Ниш: Црквене студије, 3

Рудофски, Бернард (1976): Архитектура без архитеката. Београд: Грађевинска књига

Скуп текстова Отаца цркве (2009): Добротољубље. Београд: Задужбина Светог манастира Хиландара

Софокле (1996): Антигона. Београд: Народна књига; Алфа

Хајдегер, Мартин (1982): Мишљење и певање. Београд: Нолит

Шпенглер, Освалд (2010): Пропаст запада. Београд: Утопија

Шулц, Кристијан Норберг (2000): Егзистенција, простор, архитектура. Београд: Грађевинска књига

Турк

Шулц, Кристијан Норберг (2009): Интенщије у архитектури. Загреб: Јасенски и 


\section{Slaven Stevanović}

\section{MODEL OF THE PRIMITIVE HUT ACCORDING TO THE SACRED AND THE PROFANE PARADIGM}

Man's existence on earth is spatial. The primitive hut (the first house) represents the material concretization of the human space of existence. The settings of man's space of existence are found in his personal life paradigms. Therefore, the basic task of architecture is to concretize these different human paradigms.

According to M. Eliade, two general paradigms of life are "sacred" and "profane." Modern architecture concretizes almost exclusively the "profane" human existence.

In this paper, I explore what a "sacred" human existence is, pointing out the fact that it still exists, but also that it is neglected in the architectural sense. Architecture has an ontological obligation to concretize the existential space of every human being, including the one whose life paradigm is defined as "sacred". 